International Journal of Current Microbiology and Applied Sciences

ISSN: 2319-7706 Volume 10 Number 02 (2021)

Journal homepage: http://www.ijcmas.com

\title{
Evaluation of Potential Biocontrol Agents on Root Knot Nematode Meloidogyne incognita Management in Carnation (Dianthus caryophyllus L.)
}

\author{
T. Senthil Kumar* \\ Department of Nematology, Horticultural Research Station, TNAU, Pechiparai - 629161, \\ Kanniyakumari District, Tamil Nadu, India \\ *Corresponding author
}

\section{A B S T R A C T}

Keywords

Carnation, Root knot nematode, Meloidogyne incognita, Pseudomonas fluorescens

Article Info

Accepted:

15 January 2021 Available Online: 10 February 2021
Field experiment on management of Meloidogyne incognita in Carnation var. Dona under poly house conditions was conducted to assess the efficacy of plant growth promoting rhizobacteria, single and combined application of Pseudomonas fluorescens and Bacillus subtilis. All the treatments were significantly increased the yield parameters viz., number of flowers per plant and total number of flowers per meter ${ }^{2}$ and also observed the reduction of root knot nematode population. Fifty per cent increased yield was recorded in $P$. fluorescens (Pfbv 22) @ 10g/ $\mathrm{m}^{2}$ and combined application of $P$. fluorescens (Pfbv 22) + B. subtilis (Bbv57) each @ $5 \mathrm{~g} / \mathrm{m}^{2}$ treated bed respectively compared to untreated control. The single soil application of P. fluorescens (Pfbv 22) @ 10g/ $\mathrm{m}^{2}$ and combined application of P. fluorescens (Pfbv 22) +B. subtilis (Bbv57) each @ $5 \mathrm{~g} / \mathrm{m}^{2}$ recorded lowest root knot nematode population of 62.9 and 60.5 per cent respectively compared to untreated control. However, the reduction in galls index, number of egg masses and adult nematode population was higher in P. fluorescens (Pfbv 22) @ 10/m alone treated bed.

\section{Introduction}

Carnation (Dianthus caryophyllus L.) is one among the most popular commercial cut flowers of the world, ranking second in commercial importance next only to rose. Carnation is preferred by several exporting countries, on account of its excellent keeping quality, wide range of forms, colours and ability to withstand long distance transportation. Carnation cultivation is popular in hilly regions of Tamil Nadu, India. It has become one of the most remunerative farming enterprises at present in lower pulney's of Dindigul district, Tamil Nadu, India. Frequently it was noticed that the growth of 
carnation is adversely affected, leaves turn yellow, and slowly plants die. The soil and root samples of these areas on preliminary observations revealed that root-knot nematode, Meloidogyne incognita which was found to be responsible for growth decline. The root-knot nematode, $M$. incognita which causes 25 - 30 per cent yield loss in flower crops in Tamil Nadu is one of the major constraints of cut flower production. The nematodes cause reduced root system, stunted shoot growth and reduction in the number of blooms. The carbofuran $3 \mathrm{G}$ is a very good nematicide available for nematode management, but use of this nematicide is restricted due to nematicide residues in produce, environmental pollution and health hazards. So as to avoid these problems, alternatively use of biological agents were explored to manage root knot nematode $M$. incognita. The present study was undertaken to evaluate the biocontrol potential of talk formulation viz., Pseudomonas fluorescens and Bacillus subtilis on root-knot nematode under poly house cultivation.

\section{Materials and Methods}

The talk formulation of plant growth promoting rhizobacteria (PGPR) $P$. fluorescens and B. subtilis were tested for their antinemic potential against $M$. incognita on carnation under poly house condition at lower pulney hills, Thandikudi, Dindigul District. The talk formulation of PGPR consortium is the combination of two bacterial strain $P$. fluorescens (Pfbv 22) and B. subtilis (Bbv57) developed by Jonathan et al., (2006) Department of Nematology, Tamil Nadu Agricultural University, Coimbatore was used in this experiment. Root knot nematode sick carnation growing medium was deeply tilled and added the organic matter to improve the aeration and fertility of soil. Beds are formed in the north-south direction. The bed width and height are $75 \mathrm{~cm}$ and $45 \mathrm{~cm}$ respectively.
The bed length should not exceed $25 \mathrm{~m}$. Before planting, drip lines and support netting are to be laid out. The bed should be moderately wet and drenched lightly with a fungicide (copper oxychloride @ 2 g/litre of water) to avoid fungal diseases. Planting were done at the time of evening with spacing of 15 $\mathrm{x} 15 \mathrm{~cm}$ is followed. The plants should be removed from the rooting trays carefully without damaging the roots. Planting were done at shallow depth with part of the root zone exposed. Before planting the bed was treated as per the treatment schedule viz. Soil application of $P$. fluorescens (Pfbv 22) @ 10g $/ \mathrm{m}^{2}, \quad$ B. subtilis (Bbv57) @ $10 \mathrm{~g} / \mathrm{m}^{2}, P$. fluorescens (Pfbv 22) + B. subtilis (Bbv57) each@5 g/ $\mathrm{m}^{2}$, P. fluorescens (Pf 1) @10 $\mathrm{g} / \mathrm{m}^{2}$, Carbofuran 3G @ $1 \mathrm{~kg}$ a.i./ha, along with untreated control. The experiment was laid out in randomized block design with six treatments and four replications. Observation such as soil nematode population, root gall index, number of adult female/g of root, number of egg masses/g of root was recorded 180 days after planting. Yield parameters viz., number of flowers/plant and total number of flowers $/ \mathrm{m}^{2}$ was also recorded.

\section{Results and Discussion}

The results revealed that the root knot nematode population, plant growth and flower yield were increased considerably in all the treatments compared to untreated control. Among the treatments soil application of $P$. fluorescens (Pfbv 22) @ $10 \mathrm{~g} / \mathrm{m}^{2}$ and combined application of $P$. fluorescens (Pfbv $22)+$ B. subtilis (Bbv57) each @ $5 \mathrm{~g} / \mathrm{m}^{2}$ recorded lowest root knot nematode population of 62.9 and 60.5 per cent respectively compared to untreated control. Consortium of both $P$. fluorescens and $B$. subtilis found to reduce the number of root galls and number of egg masses per gram of root. P. fluorescens (Pfbv 22) @ $10 \mathrm{~g} / \mathrm{m}^{2}$ application was recorded the number of adult 
female nematode, egg mass in one gram of root and root gall index with a reduction of 63, 65 per cent \& index 2 respectively over untreated control. Maximum number of flower per plant and flower yield per sq.m were recorded in $P$. fluorescens (Pfbv 22) $+B$. subtilis (Bbv57) each $5 \mathrm{~g} / \mathrm{m}^{2}$ treated bed when compared to untreated control. Whereas application of B. subtilis (Bbv57)@10 g/ $\mathrm{m}^{2}$, $P$. fluorescens (Pf 1) @ $10 \mathrm{~g} / \mathrm{m}^{2}$, and Carbofuran 3G @ $1 \mathrm{~kg}$ a.i./ha were found to observe significantly increased flower yield compared to untreated control (Table 1).

Table.1 Management of root knot nematode Meloidogyne incognita in carnation through PGPR consortium

\begin{tabular}{|c|c|c|c|c|c|c|}
\hline Treatments & $\begin{array}{l}\text { Nematode } \\
\text { population } \\
\text { (250g soil) }\end{array}$ & $\begin{array}{c}\text { No. of } \\
\text { female } \\
\text { /g of } \\
\text { root }\end{array}$ & $\begin{array}{c}\text { No. of } \\
\text { egg } \\
\text { mass } / g \\
\text { of root }\end{array}$ & $\begin{array}{c}\text { Gall } \\
\text { Index }\end{array}$ & $\begin{array}{c}\text { Yield } \\
\text { (No. of } \\
\text { flower/Plant) }\end{array}$ & $\begin{array}{c}\text { Yield } \\
\text { (No. of } \\
\text { flower } / \mathbf{m} 2 \text { ) }\end{array}$ \\
\hline $\begin{array}{c}\text { T1 - SA Pf (Pfbv 22) @ } 10 \\
\text { g/m } \mathbf{m}^{2}\end{array}$ & 148 & 12 & 8 & 2 & 4 & 112 \\
\hline$\underset{\mathbf{g} / \mathbf{m}^{2}}{\mathbf{T} 2 \text { - SA Bs (Bbv) } @ 10}$ & 171 & 17 & 10 & 3 & 3 & 90 \\
\hline $\begin{array}{l}\text { T3-SA Pf (Pfbv 22) + Bs } \\
\left(\text { Bbv 57) each @ } 5 \mathrm{~g} / \mathrm{m}^{2}\right.\end{array}$ & 139 & 10 & 8 & 2 & 4 & 120 \\
\hline T4-SA Pf (Pf 1) @ 10 g/m & 207 & 18 & 14 & 3 & 3 & 90 \\
\hline $\begin{array}{c}\text { T5 - Carbofuran @ } 1 \text { kg } \\
\text { a.i./ha }\end{array}$ & 137 & 8 & 7 & 2 & 3 & 90 \\
\hline T6 - Untreated control & 375 & 27 & 20 & 4 & 2 & 60 \\
\hline $\mathrm{CD}(\mathbf{0 . 0 5})$ & 14.88 & 1.43 & 1.79 & & 0.67 & 20.22 \\
\hline
\end{tabular}

* Pf - Pseudomonas fluorescens, Bs-Bacillus subtilis, SA = Soil application

The present study was designed to determine the biocontrol potential of consortium $P$. fluorescens (Pfbv 22) + B. subtilis (Bbv57) on root knot nematode in carnation. In general, all the bio agents are capable of reducing the root knot nematode $M$. incognita population in soil. The results of this study showed that combined application of $P$. fluorescens and $B$. subtilis was found to be more effective on reduction of nematode population. The population of $M$. incognita juveniles was suppressed by Pseudomonas spp. due to its nematicidal action against juveniles (Keuken and Sikora, 1995), and alteration of root exudates, which affect the hatching and mortality of juveniles (Oostendorp and Sikora, 1990) finally nematode population were reduced. Reduction of root knot nematode $M$. incognita and increased the plant growth significantly due to its plant growth promoting hormones and the bacterium was suited for both seed as well as soil application, because of their potential for rapid and aggressive root colonization (Santhi and Sivakumar, 1995). The PGPR consortium was used as soil application in black pepper reduced the population of $M$. incogntia and Radopholus similis significantly (Senthilkumar et al., 2011).

Number of flowers per plant and total number of flowers harvested from one square meter area was significantly increased in each treatment compared to untreated control. Fifty 
per cent highest yield was recorded in combined application of $P$. fluorescens (Pfbv 22) + B. subtilis (Bbv 57) each @ $5 \mathrm{~g} / \mathrm{m}^{2}$ compared to untreated control. The single and combined application of $P$. fluorescens and $B$. subtilis significantly improved the yield parameters viz., number of flowers per plant and total number of flowers harvested from one square meter area. This was due to the plant growth promoting activity and high biocontrol potential of fluorescent pseudomonads and Bacillus sp. (Shekhar Varshney and Chaube, 1999). The plant growth promoting rhizobacteria may promote growth by secreting plant hormones (Lifshits et al., 1987).

The $P$. fluorescens and $P$. aeruginosa producing gibberellic acid (Katznelson and Cole, 1965) and the production of Indole Acetic Acid by P. fluorescens (Dubeikovsky et al., 1993) was responsible for plant growth. Senthil Kumar and Rajendran (2003) also recorded increase in the yield by soil application of $P$. fluorescens with consequent management of nematode fungal disease complex in grapevine. Hence it was concluded that the consortium of P. fluorescens (Pfbv 22) + B. subtilis (Bbv 57) may be a promising practice in management of root knot nematode in carnation under poly house cultivation.

\section{References}

Dubeikovsky, A.N., E.A. Mordukhova, V.V. Polikarpora and A.M. Boronin. 1993. Growth promotion of black current soft wood cuttings by recombinant strain Pseudomonas fluorescens BSP 53a synthesizing an increased amount of indole - 3 - acetic acid. Soil Biology and Biochemistry, 25: 1277 - 1281.

Jonathan, E.I., A. Sandeep, I. Cannayane and R. Umamaheswari. 2006. Bioefficacy of Pseudomonas fluorescens on Meloidogyne incognita in banana.
Nematologia Meditteranea, 34: 19-25.

Katznelson, $H$ and S.E. Cole. 1965. Production of gibberellin substances by bacteria and actinomycetes. Canadian Journal Microbiology, 11: 733-741.

Keuken, O. and R.A. Sikora. 1995. Biological control of root knot nematode, Meloidogyne incognita with the rhizosphere bacteria Bacillus subtitles and bacterial production of toxic metabolites. Nematologica, 41: 315.

Lifshits, R., J.W. Kloepper, M. Kozlwski, C. Simonson, J. Cavison, E.M. Tipping and I. Zaleska. 1987. Growth promotion of canola (rapeseed) seedling by a strain of Pseudomonas putida under gnotobiotic conditions. Canadian Journal of Microbiology, 33: 390-395.

Oostendorp, M and R.A. Sikora. 1990. In vitro interrelationships between rhizosphere bacteria and Heterodera schachtii. Revue de Nematologie, 13: 269-274.

Santhi, A. and C.V. Sivakumar. 1995. Biocontrol Potential of Pseudomonas fluorescens (Migula) against root knot nematode, Meloidogyne incognita (kofoid and white, 1919) chitwood, 1949 on tomato. Journal of Biological control, 9: 113-115.

Senthilkumar, T. and G. Rajendran. 2003. Studies on wilt disease expression in the presence of Meloidogyne incognita and Fusarium moniliforme in grapevine. Nematologia Meditteranea, 31: 187-189

Senthilkumar, T., M. Ananthan and E. I. Jonathan. 2011. Field experiment on efficacy of Pseudomonas fluorescens (Pfbv 22) and Bacillus subtilis (Bbv57) on Meloidogyne incognita and Radopholus similis in black pepper, National Symposium on "Nematodes: A Challenge Under Changing Climate and Agricultural Practices" 16th-18th 
Nov., 2011, Kovalam, of fluorescent pseudomonads and Thiruvananthapuram, Kerala, 89 PP. Trichoderma sp. Indian Journal of Shekhar Varshney and H.S. Chaube. $1999 . \quad$ Plant Pathology, 17: 27-29. Comparative rhizosphere competence

\section{How to cite this article:}

Senthil kumar, T. 2021. Evaluation of Potential Biocontrol Agents on Root Knot Nematode Meloidogyne incognita Management in Carnation (Dianthus caryophyllus L.). Int.J.Curr.Microbiol.App.Sci. 10(02): 1786-1790.

doi: https://doi.org/10.20546/ijcmas.2021.1002.211 